\title{
Disappearing population of Betula humilis Schrk. on the Maliszewskie Lake, NE Poland
}

\author{
Agnieszka Chrzanowska* \& Katarzyna A. Jadwiszczak
}

Institute of Biology, University of Białystok, K. Ciołkowskiego 1J, 15-245 Białystok, Poland

* corresponding author (e-mail: maga.chrzanowska@gmail.com)

\begin{abstract}
Betula humilis Schrk. is an endangered glacial relict inhabiting wet meadows, natural and drained fens. One of its declining populations is located on the Maliszewskie Lake (the Wizna swamp, north-eastern Poland). The goal of the present study was to estimate the number of $B$. humilis individuals in this locality. In the Maliszewskie Lake population, 59 ramets, grouped into three clusters, were found. Twelve nuclear microsatellite loci were chosen to genotype 52 ramets. The analysis revealed that all the shoots within the single cluster had the same genotypes at the loci considered. This means that each cluster constituted one genetically distinct individual; thus, there were only three individuals of $B$. humilis in the studied population. The maintenance of the $B$. humilis population in the Maliszewskie Lake area requires urgent active protection involving removal of the shading vegetation. In fact, the entire Maliszewskie Lake is worthy of protection because of its hitherto unexplained origin and the occurrence of many endangered bird species.
\end{abstract}

Key words: Betula humilis, conservation genetics, genet, microsatellite, ramet, wetland conservation

\section{Introduction}

In land use classification, wetlands are known as wastelands in terms of both agriculture and forestry. However, biologists postulate that they are significant biodiversity units because the combination of aquatic and terrestrial conditions allows the existence of a variety of animal and plant organisms, including many endangered species (Bacon 1997; Fujita et al. 2014). Wetlands also play a very important role in water retention, limitation of soil erosion, lowering the risk of flood and in water quality improvement by serving as filters. In addition, wetlands act as resting and feeding places for some birds during their spring and autumn migrations. Unfortunately, the area of the world's swamps has declined by half during recent centuries (Keddy 2000). In Poland, the loss of mires has reached more than $80 \%$ (Wolejko et al. 2005), which is mainly a consequence of drainage. The overgrowth of drained fens and meadows by reeds, shrubs and trees reduces their areas and initiates the decline of mire habitats. These processes could have a disastrous impact on wetland species, ranging from reductions in the numbers of individuals to a complete disappearance of populations.
Wizna swamp is one of the biggest declining fens in Poland. Until the First World War, the central part of the mire, drained by poor systems of ditches, was used to a small extent by farmers who mowed the grass for cattle and horses (Kołos \& Próchnicki 2004). During this time, some parts of the swamp were particularly valuable in terms of natural diversity, as they were populated by numerous specimens representing rare plant species in Poland, including Herminium monorchis, Pedicularis sceptrumcarolinum, Schoenus ferrugineus, Swertia perennis and two sedge species, Carex chordorriza and C. limosa (see Kołos \& Próchnicki 2004). The abandonment of mowing after the Second World War caused the overgrowth of the Wizna swamp by bushes. However, drainage conducted in the whole fen from 1962 to 1971 changed this region completely. Previous communities of bushes, dominated by Betula pubescens, Frangula alnus, Populus tremula, Salix cinerea, Viburnum opulus and two glacial relicts, Betula humilis and Salix lapponum, were extirpated and replaced by high fodder productivity grasslands (Kołos \& Próchnicki 2004). Almost 6,000 hectares of drained mire were included into the State Agricultural Farm "Wizna".

Although the adverse effects of drainage are visible in all parts of the Wizna mire, there are three 
parts that are relatively undisturbed, namely: "Biel" and "Grzędy" ranges as well as the vicinity of the Maliszewskie Lake (Kołos \& Próchnicki 2004). Some authors have suggested that the Maliszewskie Lake could be one of four old glacial water reservoirs in the Północnopodlaska Plain (north-eastern Poland), and the only one in the Narew river valley (Banaszuk 2004; Kołos \& Tarasewicz 2005). It is surrounded by topogenic-soligenic mire, where $B$. humilis can still be found. B. humilis has been classified in the EN (endangered) category of the International Union for Conservation of Nature (IUCN) in central and western Europe (Załuski et al. 2014). The disappearance of its populations is mainly a consequence of the lowering of groundwater levels and a decline in the use of wet meadows. An inventory carried out at the end of the twentieth century revealed that the number of $B$. humilis stands in Poland diminished to approximately $20 \%$ of the former number (Załuski et al. 2014). The B. humilis population located on the Maliszewskie Lake also seems to be threatened because the lake is becoming smaller and shallower, which are both effects of the drainage conducted in the 1960s. Environmental monitoring by the General Inspection of Nature Protection showed that the ecological status of the lake was unsatisfactory (U1 category; Wilk-Woźniak et al. 2012). Specifically, the reduction of the lake surface and shallowing caused the overgrowth of trees and scrub vegetation. Conse- quently, the growth of the light-demanding $B$. humilis is disadvantaged in the shaded stands, and its population has declined in such places (Jabłońska 2012). The goal of this paper is to estimate the number of $B$. humilis individuals in the Maliszewskie Lake population and to propose suitable conservation practices.

\section{Material and methods}

The studied B. humilis population is located on the western side of the Maliszewskie Lake (N 53 ${ }^{\circ} 10^{\prime} 07.8^{\prime \prime}$, E $\left.22^{\circ} 30^{\prime} 45.5^{\prime \prime}\right)$, ca. $44 \mathrm{~km}$ west of the city of Białystok (Fig. 1). The marginal zone of the lake is dominated by Thelypteridi-Phragmitetum and Phragmitetum australis (Kołos \& Próchnicki 2004). Bulrush vegetation directly surrounding the lake is separated from the adjacent fields and meadows by a narrow belt of forest with Betula pubescens and Salix cinerea. Three clusters of B. humilis shoots were found in this forest. The clusters were designated as follows: A, B and C. In total, 59 ramets were counted in the three clusters, with nine in cluster A, 23 in B and 27 in C. Some ramets were very young and small. Thus, one leaf was taken from every ramet having more than three leaves. Altogether, 52 ramets were sampled, of which eight were in cluster A, 21 - in B and 23 - in C (Table 1). The samples were collected with the permission of the Regional Director of Environmental Protection in Białystok (WPN. 6400.45.2013.AP).

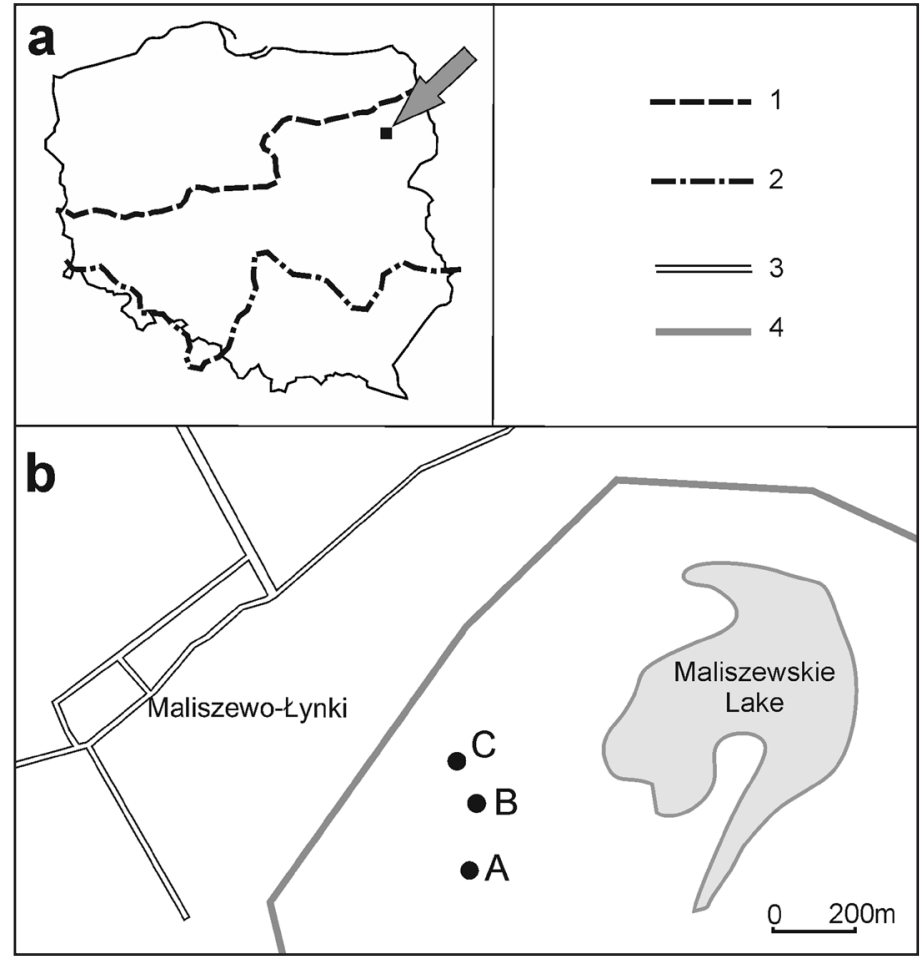

Fig. 1. Location of Betula humilis population in NE Poland (a), on the Maliszewskie Lake (b)

Explanations: A, B and C - location of genetic clusters of B. humilis on the Maliszewskie Lake; 1 - limit of the ice-sheet in the Vistulian Glaciation, 2 - limit of the ice-sheet in the Odranian Glaciation, 3 - road, 4 - ditch 
The leaf material was transferred to the laboratory in a car refrigerator and stored at $-80^{\circ} \mathrm{C}$ until analysis. Before DNA extraction, leaves were dried at room temperature for one day. Next, they were homogenised with the TissueLyser mill (Qiagen) using steel balls. Total genomic DNA was extracted using an AX Plant Kit (A\&A Biotechnology), according to the manufacturer's procedure. To determine the genotype of each ramet, 12 nuclear microsatellite primer pairs, originally designed for B. pendula (L1.10, L2.7, L13.1, L5.4, L4.4, L5.1, L3.1, L2.3, L022; Kulju et al. 2004) and B. pubescens ssp. tortuosa (Bo.G182, Bo.F394, L021; Truong et al. 2005), were chosen. The combinations of primers into four multiplex PCRs, the proportions of the PCR reaction components and the PCR profile for each multiplex were as previously described by Jadwiszczak et al. (2011a). The separation of fluorescently labelled amplified fragments was conducted on an ABI PRISM 3130 sequencer (Applied Biosystems) and scored using GeneMapper 4.0 (Applied Biosystems) analysis software.

\section{Results and discussion}

Successful amplification was obtained for all nuclear microsatellite loci of the $B$. humilis ramets studied, except for the L4.4 locus in the cluster B (Table 1). The lack of amplification in B ramets at the L4.4 locus likely resulted from mutations occurring at primer sites, leading to the appearance of null alleles (van Oosterhout et al. 2004). This result strongly suggests that the B ramets had the same homozygous genotype at this locus. Further analysis revealed that all shoots belonging to the same cluster had identical alleles at all the microsatellite loci considered. This means that each cluster constituted one genetically distinct individual (genet); hence, there were only three specimens of $B$. humilis in the Maliszewskie Lake population. A similar result was previously obtained in the four populations of endangered Haloragodendron lucasii (northern
Sydney, New South Wales, Australia), where 53 ramets were sampled and only six multilocus genotypes were observed at allozyme and RAPD loci (Sydes \& Peakall 1998).

All individuals in the Maliszewskie Lake population were homozygotes at L13.1 and L2.3 loci. In general, these loci showed a very low level of polymorphism in B. humilis, as the previous analysis of 327 specimens from 18 populations from Poland and Belarus revealed four alleles at the L13.1 locus and three at L2.3 (Jadwiszczak et al. 2011a). Loci L2.7, L5.4, L5.1, Bo.F394 and L022 were heterozygous in all the analysed genets, and the remaining loci were heterozygous or homozygous, depending on the individual studied. Allele sizes of particular microsatellites detected in the Maliszewskie Lake population were in the size ranges described previously in other $B$. humilis locations (Jadwiszczak et al. 2011a, 2011b). We did not find any unique or private allele in the Maliszewskie Lake stand; however, this result was not surprising. The population of $B$. humilis in the Wizna mire underwent a severe reduction in numbers during drainage in 1960s. Low frequency alleles are lost rapidly during bottlenecks because the elimination of any specimen having unique alleles in their genotype results in the disappearance of such alleles (Nei et al. 1975; Luikart \& Cornuet 2008). Moreover, the effective population size of the bottlenecked populations is significantly reduced, which consequently causes a further reduction in the allele number (Cornuet \& Luikart 1996).

Unfortunately, genetic erosion, which occurs characteristically in small populations, can dramatically influence their resistance to diseases and parasites, as well as their ability to cope with environmental changes (Ellstrand \& Elam 1993; Lacy 1997). In general, $B$. humilis shows a wide spectrum of ecological tolerance. Jabłońska (2012) distinguished the following seven types of habitats populated by the species: Sphagnum moss-small sedge poor fens with a high contribution of bog species from the Oxycocco-Sphagnetea class,

Table 1. Genotypes at the nuclear microsatellite loci of Betula humilis ramets collected in the three clusters on the Maliszewskie Lake

\begin{tabular}{|c|c|c|c|c|c|c|c|c|c|c|c|c|c|}
\hline \multirow[b]{2}{*}{ Cluster } & \multirow{2}{*}{$\begin{array}{l}\text { No of } \\
\text { ramets }\end{array}$} & \multicolumn{12}{|c|}{ Microsatellite loci } \\
\hline & & $\begin{array}{c}\mathrm{L} \\
1.10\end{array}$ & $\begin{array}{c}\mathrm{L} \\
2.7\end{array}$ & $\begin{array}{c}\mathrm{L} \\
13.1\end{array}$ & $\begin{array}{c}\mathrm{L} \\
5.4\end{array}$ & $\begin{array}{c}\mathrm{L} \\
4.4\end{array}$ & $\begin{array}{c}\mathrm{L} \\
5.1\end{array}$ & $\begin{array}{c}\text { Bo.G } \\
182\end{array}$ & $\begin{array}{c}\text { Bo.F } \\
394\end{array}$ & $\begin{array}{c}\mathrm{L} \\
3.1\end{array}$ & $\begin{array}{c}\mathrm{L} \\
2.3\end{array}$ & $\begin{array}{c}\mathrm{L} \\
021\end{array}$ & $\begin{array}{c}\mathrm{L} \\
022\end{array}$ \\
\hline \multirow{2}{*}{ A } & \multirow{2}{*}{8} & 177 & 175 & 080 & 247 & 279 & 286 & 129 & 140 & 215 & 198 & 190 & 171 \\
\hline & & 177 & 179 & 080 & 253 & 279 & 300 & 129 & 150 & 217 & 198 & 192 & 195 \\
\hline \multirow{2}{*}{ B } & \multirow{2}{*}{21} & 187 & 175 & 080 & 235 & na & 298 & 127 & 134 & 217 & 198 & 194 & 181 \\
\hline & & 191 & 179 & 080 & 247 & na & 326 & 133 & 148 & 217 & 198 & 200 & 197 \\
\hline \multirow{2}{*}{$\mathrm{C}$} & \multirow{2}{*}{23} & 175 & 173 & 080 & 241 & 263 & 288 & 129 & 148 & 217 & 198 & 200 & 179 \\
\hline & & 187 & 183 & 080 & 257 & 271 & 300 & 133 & 170 & 217 & 198 & 200 & 203 \\
\hline
\end{tabular}

Explanation: na - no amplification 
brown moss-small sedge subneutral fens with the highest number of mesotrophic subneutral fen species from the Scheuchzerio-Caricetea nigrae class, brown moss-small sedge alkaline fens with species from the Caricion davallianae alliance, strongly degraded fens dominated by Urtica dioica and Galium aparine, spring mires with water rich in $\mathrm{Mg}^{2+}$ and $\mathrm{Ca}^{2+}$ ions and alkaline fen meadows. It was found that the maintenance of $B$. humilis in its habitats depended on calcium concentration and water level. Both high $\mathrm{Ca}^{2+}$ concentrations and high water levels prevented the spread of other plants and enabled the growth of light-demanding $B$. humilis (Jabłońska 2006). In the Maliszewskie Lake population, the concentration of calcium ions is rather average, compared to other B. humilis localities (Jabłońska 2009; Jadwiszczak et al. 2015), which could have weakened the competitive ability of this species. However, the water table in the Maliszewskie Lake seems to be advantageous for the species, as it is around the peat surface (Jabłońska 2009, 2012). In addition to the relatively high water table, $B$. humilis in the Maliszewskie Lake clearly suffers due to shading by other shrub and tree species. It is likely that the dominance of shading vegetation results from year to year variations in the water level in this locality, which depends on rainfall. In dry years, brushwood and forest species might spread increasingly and displace $B$. humilis. In the undisturbed mires, e.g., the Rospuda mire in north-eastern Poland, stable hydrologic conditions allow the existence of a stable and long-lasting $B$. humilis population (Jabłońska et al. 2011).

Populations of $B$. humilis located in north-eastern Poland are located mainly in national parks, landscape parks or reserves. However, active conservation practices are not used in these locations (Matowicka \& Jabłońska 2008). It is obvious that the maintenance of $B$. humilis on the Maliszewskie Lake requires urgent active protection, such as the removal of brushwood and forest plants, at least around the existing clusters of the species. This should be followed by water retention enhancement, which should stop the succession of other species. In the present habitat conditions, the transplantation of $B$. humilis individuals from the adjacent populations is not recommended because there is little chance for their acclimation.

The Maliszewskie Lake is a unique place not only because of the presence of the endangered glacial relict $B$. humilis. In addition, its unexplained origin and huge richness of birds make it extremely valuable for conservation. The results of palynological investigations suggest that the Maliszewskie Lake arose as a result of melting of ground ice blocks (Stasiak 1979; Żurek et al. 2002; Banaszuk 2004). However, that part of Poland was not covered by ice sheets during the last glaciation (Fig. 1). Could the lake be dated back to the third of the Middle Polish Glaciations, the Odranian Glaciation (210-130 ka BP)? This hypothesis seems to be confirmed by a relatively small area of the lake, its shallowness (the maximum depth is $80 \mathrm{~cm}$ ) and its very thick layer of sediments (22.5 m; Stasiak 1979). However, the beginning of biogenic layer formation was previously dated to the Alleröd interstadial of the Late Vistulian (see Żurek et al. 2002).

The Maliszewskie Lake is a paradise for ornithologists. Among others, such endangered bird species as: Philomachus pugnax and Acrocephalus paludicola can be observed here (Zakrzewska 2010). As such, the conservation of the Maliszewskie Lake habitat and increasing publicity could help to relieve and protect the adjacent Biebrza National Park, which is particularly important during the spring migration of birds, when large numbers of tourists and bird-watchers visit the park (Zakrzewska 2010).

Acknowledgement. We thank Ms. Ewelina Jaworowska M.Sc. for her help in sample collection.

\section{References}

BACON P. 1997. Wetlands and biodiversity. In: A. J. HALLS (ed.). Wetlands, biodiversity and the Ramsar convention: the role of the convention on wetlands in the conservation an wise use of biodiversity, pp. 1-17. Ramsar Convention Bureau, Gland, Switzerland.

BanaszuK H. 2004. Geomorfologia Kotliny Biebrzańskiej. In: H. Banaszuk (ed.). Kotlina Biebrzańska i Biebrzański Park Narodowy. Aktualny stan, walory, zagrożenia i potrzeby czynnej ochrony środowiska. Monografia przyrodnicza, pp. 44-98. Wyd. Ekonomia i Środowisko, Białystok.
Cornuet J.-M. \& Luikart G. 1996. Description and power analysis of two tests for detecting recent population bottlenecks from allele frequency data. Genetics 144: 2001-2014.

Ellstrand N. C. \& Elam D. R. 1993. Population genetic consequences of small population size: implications for plant conservation. Ann. Rev. Ecol. Syst. 24: 217-242.

Fujita Y., Venterink H. O., van Bodegom P. M., Douma J. C., Heil G. W., Hölzel N., JabŁońska E., Kotowski W., Okruszko T., PAwlikowski P., De Ruiter P. \& Wassen, M. J. 2014. Low investment in sexual reproduction 
threatens plants adapted to phosphorus limitation. Nature 505: 82-86.

JABŁOŃSKA E. 2006. Comparison of habitat conditions at Betula humilis sites in north-eastern and south-eastern Poland. Pol. J. Environ. Stud. 15: 181-187.

JABŁoŃSKA E. 2009. Brzoza niska Betula humilis Schrank w Polsce - status fitocenotyczny, warunki siedliskowe, zagrożenia i ochrona, $\mathrm{Ph}$. D. Thesis, Institute of Botany, Warsaw University, Warsaw, Poland.

JABŁOŃSKA E. 2012. Vegetation with Betula humilis in Central Europe. Phytocoenologia 42: 259-277.

JABŁoŃSKa E., PAWLIKowsKi P., JARZOMBKOWSKI F., CHORMAŃSKI J., OKruszko T. \& KŁosowski S. 2011. Importance of water level dynamics for vegetation patterns in a natural percolation mire (Rospuda fen, NE Poland). Hydrobiologia 674: 105-117.

JADWISZCZAK K. A., BANASZEK A., JABŁoŃSKA E. \& SozINOv O. V. 2011a. Could Betula humilis Schrk. have survived the last glaciation at a current margin of its distribution? - testing the hypothesis of glacial refugium using nuclear microsatellites. Plant Syst. Evol. 297: 147-156.

JADWiszCZAK K. A., JABŁońSKA E. \& BANASZeK A. 2011 b. Genetic diversity of the shrub birch Betula humilis Schrk. at the south-western margin of its range. Plant Biosyst. 145: 893-900.

Jadwiszczak K. A., JabŁońska E., KŁosowski S. \& BanaszeK A. 2015. Genetic variation and habitat conditions in Betula humilis Schrk. populations in Poland, Belarus and Latvia. Plant Biosyst. 149: 433-441.

KedDy P. A. 2000. Wetland ecology: principles and conservation. 497 pp. Cambridge University Press, Cambridge.

KoŁos A. \& Próchnicki P. 2004. Zastosowanie retrospektywnej analizy zdjęć lotniczych w projektowaniu zabiegów renaturalizacyjnych na torfowisku Wizna (Dolina Narwi). Teledetekcja Środowiska 33: 3544.

Kolos A. \& TARASEWICZA. 2005. Czynna ochrona zagrożonych systemów jeziornych Niziny Północnopodlaskiej na przykładzie jeziora Wiejki. Chrońmy Przyr. Ojcz. 61: 41-57.

Kuluu K. K. M., Pekrinen M. \& Varvio S. 2004. Twentythree microsatellite primer pairs for Betula pendula (Betulaceae). Mol. Ecol. Notes 4: 471-473.

LACY R. C. 1997. Importance of genetic variation to the viability of mammalian populations. J. Mammal. 78: 320-335.

LuikART G. \& CoRnuet J.-M. 2008. Empirical evaluation of a test for identifying recently bottlenecked populations from allele frequency data. Conserv. Biol. 12: 228-237.

Matowicka B. \& JabŁońska E. 2008. Ochrona populacji brzozy niskiej Betula humilis (Betulaceae) na Nizinie Północnopodlaskiej. In: K. KolAnKo (ed.). Różnorodność badań botanicznych - 50 lat Białostockiego Oddziału Polskiego Towarzystwa
Botanicznego 1958-2008, pp. 45-55. EkoPress, Białystok.

Nei M., Maruyama T. \& Chakraborty R. 1975. The bottleneck effect and genetic variability in populations. Evolution 29: 1-10.

Stasiak J. 1979. Wiek jeziora Maliszewskiego i bagien w Kotlinie Biebrzy. Pr. i Stud. Inst. Geog. UW 8: 129-172.

Sydes M. A. \& Peakall R. 1998. Extensive clonality in the endangered shrub Haloragodendron lucasii (Haloragaceae) revealed by allozymes and RAPDs. Mol. Ecol. 7: 87-93.

Truong C., Palmé A. E., Felber F., Naciri-Graven Y. 2005. Isolation and characterization of microsatellite markers in the tetraploid birch, Betula pubescens ssp. tortuosa. Mol. Ecol. Notes 5: 96-98.

Van Oosterhout C., Hutchinson W. F., Wills P. M. \& SHIPLEy P. 2004. MICRO-CHECKER: software for identifying and correcting genotyping errors in microsatellite data. Mol. Ecol. Notes 4: 535-538.

Wilk-Woźniak E., Gąbka M., Pęczula W., Burchardt L., Cerbin S., Glińska-Lewczuk K., Goldyn R., Grabowska M., Karpowicz M., Klimaszyk P., KoŁodziejczyk A., KoKociński M., Kraska M., KuCZyŃSKA-KipPen N., Ligęza S., Messyasz B., Nagengast B., Ozimek T., Paczuska B., Pelechaty M., Pietryka M., Piotrowicz R., Pociecha A., Pukacz A., Richter D., Walusiak E. \& ŻBIKOWSKI J. 2012. Starorzecza i naturalne eutroficzne zbiorniki wodne ze zbiorowiskami z Nympheion, Potamion. In: W. Mróz (ed.). Monitoring siedlisk przyrodniczych. Przewodnik metodyczny. Część II. GIOŚ, Warszawa, pp. 130-149.

WoŁejko L., Herbichowa M. \& Potocka J. 2005. Typological differentiation and status of Natura 2000 mire habitats in Poland. In: G. M. Steiner (ed.). Moore von Sibirien bis Feuerland (Mires from Siberia to Tierra del Fuego), Stapfia 85, pp. 175-219. Biologiezentrum der Oberösterreichischen Landesmuseen, Linz.

ZAKRZEWSKA R. 2010. Równowaga między rozwojem rolnictwa, turystyki i ochroną środowiska na przykładzie jeziora Maliszewskiego. In: Współpraca transgraniczna na rzecz bioróżnorodności i zrównoważonego rozwoju obszarów cennych przyrodniczo, pp. 40-45. Project of Transboundary Partnership, Foxit Corporation. http:// www.fpr.org.pl/files/PUB\%20bnb\%20POL.pdf

ZaŁuski T., JabŁońska E., Pawlikowski P., Pisarek W., KucharczyK M. 2014. Betula humilis Schrank. In: R. Kaźmierczakowa, K. ZarzycKi \& Z. MireK (eds.). Polska Czerwona Księga Roślin, Paprotniki i rośliny kwiatowe, wyd. 3, pp. 92-95. PAN, Instytut Ochrony Przyrody, Kraków.

Żurek S., MichczyŃSka D. J. \& PAZdur A. 2002. Time record of palaeohydrologic changes in the development of mires during the late glacial and holocene, North Podlasie Lowland and Holy Cross mts. Geochronometria 21: 109-118. 